J. Asiat. Soc. Bangladesh, Sci. 39(2): 201-209, December 2013

\title{
PERFORMANCES OF 2 PHENOXYETHANOL AND QUINALDINE WITH OXYGEN IN THE LIVE TRUCK TRANSPORTATION OF ROHU FINGERLINGS
}

\author{
MAHMUD HASAN ${ }^{1}$, NADIA ISLAM PINKY, MD. ALAMGIR KABIR, \\ SALIM AHMED ${ }^{2}$ AND S. M. MAHBUBUR RASHID ${ }^{2}$ \\ Department of Fisheries, University of Dhaka, Dhaka-1000, Bangladesh \\ ${ }^{2}$ Department of Genetic Engineering and Biotechnology, University of Dhaka, \\ Dhaka-1000, Bangladesh
}

\begin{abstract}
The effectiveness of 2 phenoxyethanol (2 PE), quinaldine (2-methyl quinoline), benzocaine (ethyl 4 aminobenzoate) and tertiary amyl alcohol (TAA) was tested to determine their optimal dosages for rapid induction and recovery in the first experiment, while the second experiment evaluated the effects of low dose quinaldine $(175 \mu 1 / \mathrm{L})$ and $2 \mathrm{PE}(250 \mu \mathrm{l} / \mathrm{L})$ with oxygen for $1,3,6$ and $9 \mathrm{~h}$ on the mortality and water qualities at $400 \mathrm{~g} / \mathrm{L}$ rohu Labeo rohita fingerlings in a truck transport simulation. Optimum dosages of $2 \mathrm{PE}(250 \mu \mathrm{l} / \mathrm{L})$, quinaldine $(175 \mu \mathrm{l} / \mathrm{L})$, benzocaine $(40 \mathrm{mg} / \mathrm{L})$ and TAA $(1.5 \mathrm{ml} / \mathrm{L})$ were found to have rapid (within $6 \mathrm{~min}$ ) immobilization and recovery. Very low level of immediate and delayed mortality $(<1 \%)$ was found across all three transport methods. While $2 \mathrm{PE}$ had dissolved oxygen (DO) concentration above $13 \mathrm{mg} / \mathrm{L}$, quinaldine had lower level. Results suggest that rohu fingerlings at $400 \mathrm{~g} / \mathrm{L}$ can be transported for 9 hours with oxygen with or without sedatives.
\end{abstract}

Key words: 2 Phenoxyethanol, Quinaldine, Oxygen, Transportation, Rohu fingerlings

\section{Introduction}

Rohu is a high valued cultured fish in Bangladesh contributing $24.84 \%$ to the country's total pond production (DoF 2008). This fish fetches a good market price and consumer demand. Typically, small batches of rohu fingerlings $(25 \mathrm{~kg})$ are packed into plastic drum (200 L), given hand agitation carried on truck-beds for transportation to cover distances as much as $500 \mathrm{~km}$. Handling stress, however, can result in large-scale mortalities of fish transported over long distances; especially if high densities of fish are maintained during transit (Smit 1980). Hasan and Bart (2006) have estimated the annual loss (6200 mt) of carp fingerlings resulting from mortality due to transport stress which is nearly 13.62 million US\$ in Bangladesh.

Modern aquaculture practices frequently expose fish to a variety of acute stresses that have the potential to negatively affect fish performance for survival (Barton 2000). The

\footnotetext{
${ }^{1}$ Corresponding author: E-mail: mhasan@du.ac.bd
} 
effects of stress can be manifested at several levels of biological organizations from subcellular to individual, population and community levels by altering the plasma hormones, physiological activities such as iono-osmotic function, metabolism and growth rates (Adams 1990, Pickering 1992 and 1993, McCormick et al. 1998 and Weil et al. 2001). Higher survival, better health and growth can be achieved by minimizing stress, maintaining good water quality, proper loading density and less stressful handling and transportation. One method commonly used to mitigate or minimize the effect of stress on fish is the use of sedatives (McFarland 1959 and Berka 1986).

Anesthesia has been introduced as an aid to prevent stress in fish for long time (Coyle et al. 2004). It also reduces excitement and hyperactivity-related trauma that can occur during routine handling and thus directly reduces mortality. The decrease in movement minimizes skin damage, associated osmoregulatory disturbances (Kumlu and Yanar 1999) and reduces metabolism, resulting in decreased oxygen demand and the production of less waste (i.e., $\mathrm{CO}_{2}$ and ammonia) during transportation (Guo et al. 1995, Pirhonen et al. 2003 and Cooke et al. 2004). Use of sedatives generally depends on their efficacy, availability, cost-effectiveness and safety.

Among different sedatives, quinaldine was found to be more effective in alkaline water, efficient at low dose and less toxic with a shorter recovery period (Bell 1964, Sills and Allen 1973, Lambert 1982 and Coyle et al. 2004). Quinaldine (25 mg/L) induced light sedation in tilapia (Sarotherodon melanotheron) fingerlings $(3-13 \mathrm{~cm}$ ) (Sado 1985). Quinaldine was also found to induce quick lethargy and recovery in sea bream (Sparus sarba) fingerlings (3-3.5 g) compared to other sedatives (e.g., quinate, MS-222, benzocaine and 2 phenoxyethanol (Hseu et al. 1998). Munday and Wilson (1997) reported quinaldine as the most effective anesthetic to induce total loss of equilibrium compared to benzocaine, MS 222, 2 phenoxyethanol and clove oil. Durve (1975) achieved 97\% survival of mullet Mugil cephalus, Liza tade fry/fingerlings using quinaldine during $24 \mathrm{~h}$ transport while Lambert (1982) recommended a lower dose (1-4 $\mathrm{mg} / \mathrm{L}$ ) to minimize handling stress in yearling Atlantic mackerel (Scomber scrombrus). However, in fish $95 \%$ clearance of quinaldine was found within $24 \mathrm{~h}$ of withdrawal (Hunn and Allen 1974). Hasan and Bart (2007a) have demonstrated that low dose quinaldine with mechanical aeration can be used for high density $(400 \mathrm{~g} / \mathrm{L})$ long distance (6 h) safe transport (no mortality) of silver carp (Hypophthalmichthys_molitrix) and rohu fingerlings.

Two phenoxyethanol is an opaque, colorless, a moderately water-soluble clear or strawcolored oily and aromatic liquid. It is relatively inexpensive and remains active in the diluted state for 3 days (Hseu et al. 1998). Coyle et al. (2004) suggested that MS 222, benzocaine, quinaldine, 2 phenoxyethanol, metomidate, clove oil, $\mathrm{CO}_{2}$, hypothermia and electro-anesthesia as useful in the transportation of fish. The efficacy of 2 phenoxyethanol varies with the size of the fish and with the temperature of the water. 
Benzocaine and quinaldine have been found to be used successfully for transportation of rohu and silver carp fingerlings with mechanical aeration at a loading density of $400 \mathrm{~g} / \mathrm{L}$ (Hasan and Bart 2007a). But 2 phenoxyethanol has never been reported in the transport of rohu fingerling with oxygen. In a moving truck bed, lack of power prevents from using mechanical aerator to diffuse oxygen. However, use of oxygen instead of mechanical aerator would provide the most valuable life support for the fingerlings without requirement of any energy during long distance transport.

This study, therefore, was designed to determine the efficacy of 2 phenoxyethanol, quinaldine, benzocaine and tertiary amyl alcohol and effects of quinaldine and 2 PE with oxygen on the mortality and water quality variables in rohu fingerlings.

\section{Materials and Methods}

Rohu fingerlings $(9.37 \pm 0.09 \mathrm{~cm} ; 9.66 \pm 0.22 \mathrm{~g}$; mean $\pm \mathrm{SE})$ were collected from the "Ma Fatema Fish Hatchery", Chachra, Jessore, Bangladesh, some 6-7 hours bus ride from the capital city Dhaka for getting reliable supply of the fingerlings throughout the entire experimental period. The experiments were carried out in the hatchery between May and June 2011. For simulation purposes, the fingerlings were held in flow-throughtank system with vertical spray. Feeding was suspended 12 hours before loading the fingerlings in to transport drums.

Efficacy of 2 PE, quinaldine, benzocaine and TAA was tested in a series of preliminary trials to determine the appropriate dosages which works best to properly tranquilize rohu fingerlings in 2-4 min with no or lowest mortality depending on the availability in the local market and associated cost. Several aluminum vessels $(10 \mathrm{~L})$ were filled with $1 \mathrm{~L}$ well water and mixed with one sedative of several dosages to observe the mobility of the fingerlings. Initial DO content and temperature of the water were also monitored. Afterwards 15 rohu fingerlings were released in each vessel. The changes in the condition of the fingerlings in different vessels were observed over 1, 3, 6 and 9 hour duration. The time requirements in terms of immobilization and recovery of the rohu fingerlings exposed to different sedatives were determined.

All sedatives were purchased from Sigma-Aldrich. To determine the optimal dosages, 2 $\mathrm{PE}$ at the rate of $0.20,0.25$ and $0.30 \mathrm{ml} / \mathrm{L}$; quinaldine (4\%) 50, 175, 200, 225 and 250 $\mu \mathrm{l} / \mathrm{L}$; benzocaine 30,40 and $50 \mathrm{mg} / \mathrm{L}$ and TAA (2-methyl 2-butanol) 1.5, 2.0, 2.5, 3.0 and $4.0 \mathrm{ml} / \mathrm{L}$ were applied. Mobility of fish fingerlings during application of different dosages of the above mentioned sedatives was observed. From the efficacy test quinaldine $(175 \mu \mathrm{l} / \mathrm{L})$ and $2 \mathrm{PE}(250 \mu \mathrm{l} / \mathrm{L})$ were selected to use in the transport simulation.

A $3 \times 4$ factorial design was used in triplicates by truck. The experimental variables were three transport methods and four (1,3,6 and $9 \mathrm{~h})$ transport durations. The indicator 
variables were immediate and delayed mortality. Water quality variables such as dissolved oxygen (DO) concentration and temperature were also measured.

Plastic drums of $200 \mathrm{~L}$ filled with $100 \mathrm{~L}$ subsurface well water was used as the experimental system. For simulation purpose, each drum was loaded with $40 \mathrm{~kg}$ fingerlings at $400 \mathrm{~g} / \mathrm{L}$ loading density. Before loading, sedatives were mixed well with water and oxygen was injected. Oxygen cylinder containing $9.8 \mathrm{~m}^{3}$ pure $(99.9 \%)$ oxygen at 2200 PSI was used as the source of oxygen and released at 8 PSI. Dead fingerlings were removed and counted to determine the immediate mortality rate at 1, 36 and $9 \mathrm{~h}$ after transport. Water quality variables were also measured at the time of fingerling sampling for mortality. After collection, samples were held in frozen condition at $-20^{\circ} \mathrm{C}$. For determination of delayed mortality after simulation experiment, dead fingerlings were removed from stocking hapa and counted 24 hours after the experiment began. Dissolved oxygen concentration and temperature of transport water were measured by using a portable DO meter (HACH sension ${ }^{\mathrm{TM}} 6$, USA) after 1, 3, 6 and $9 \mathrm{~h}$ of transport simulation. The results were subjected to statistical evaluation. All percent data were transformed into square root before statistical analysis. Treatments were compared by ANOVA followed by Tukey's HSD post hoc for multiple comparisons. Data were analyzed by using SPSS software version 10.0 with the level of significance at $\mathrm{p}<0.05$.

\section{Results and Discussion}

Efficacy tests: Optimum doses of four sedatives for complete immobilization and recovery were found to vary (Table 1). Apparently better result was found when TAA was applied. Because of unavailability and high cost, TAA was not used in the simulation experiment.

In efficacy test, low dose $(1.5 \mathrm{ml} / \mathrm{L})$ of tertiary amyl alcohol gave better result for immobilization and recovery of fingerlings. Quinaldine $(175 \mu \mathrm{l} / \mathrm{L}), 2$ phenoxyethanol $(250 \mu \mathrm{l} / \mathrm{L})$ and benzocaine $(40 \mathrm{mg} / \mathrm{L})$ were also found to be very effective at low dose. All four anesthetics at different optimal doses were found to impart light sedation in rohu fingerlings, above which significant loss of equilibrium and mortality resulted. The effective concentration of an ideal anesthetic was defined as the minimum concentration that produced anesthesia within $4 \mathrm{~min}$ and allowed recovery within $5 \mathrm{~min}$. This study has clearly demonstrated that compressed oxygen and low-dose of quinaldine and $2 \mathrm{PE}$ are effective in the transportation of rohu fingerlings for a period of $9 \mathrm{~h}$. Hasan and Bart (2007b) have found overall low level (4-12\%) immediate and high level (27-49\%) delayed mortality in rohu fingerlings when transported for 9 hours at 200, 300 and 400 $\mathrm{g} / \mathrm{L}$ loading densities without any sedative and oxygen, but with only hand splashing of water. However, much higher levels of immediate (38 and 83-92\%) and delayed mortality (90\%) have been observed in carps, large mouth bass (Micropterus salmoides), freshwater drum (Aplodinotus grunneiens) and striped bass (Morone saxatilis) (Johnson 
and Metcalf 1982, Carmichael et al. 1984, Mazik et al. 1991, Lewis et al. 1996). From this study, it was found that longer period transport of rohu fingerlings caused a significant decrease in DO concentration especially in the control group. Although temperature had an increasing trend in all treatments, it was less variable. Low level of mortality $(<1 \%)$ in every transport method suggests that rohu fingerlings at a loading density of $400 \mathrm{~g} / \mathrm{L}$ can be transported successfully for $9 \mathrm{~h}$ with high rate of survival aided with low dose quinaldine, $2 \mathrm{PE}$ and pure oxygen.

Table 1. Anesthetics and their doses with levels of immobilization.

\begin{tabular}{|c|c|c|}
\hline Anesthetics & Dose & State of the findings \\
\hline \multirow[t]{3}{*}{$\begin{array}{l}2 \\
\text { Phenoxyethanol }\end{array}$} & $0.20 \mathrm{ml} / \mathrm{L}$ & $\begin{array}{l}\text { Some fishes found immobilized and some with little } \\
\text { mobility within } 5 \text { minutes }\end{array}$ \\
\hline & $0.25 \mathrm{ml} / \mathrm{L}$ & All fishes found completely immobilized within 5 minutes \\
\hline & $0.30 \mathrm{ml} / \mathrm{L}$ & All fishes found upside down within 5 minutes \\
\hline \multirow{5}{*}{$\begin{array}{l}\text { Quinaldine } \\
(4 \%)\end{array}$} & $50 \mu \mathrm{l} / \mathrm{L}$ & No lethargy found within 2 minutes \\
\hline & $175 \mu \mathrm{l} / \mathrm{L}$ & All fishes found completely immobilized within 2 minutes \\
\hline & $200 \mu \mathrm{l} / \mathrm{L}$ & $\begin{array}{l}\text { Some fishes found immobilized and some upside down } \\
\text { within } 2 \text { minutes }\end{array}$ \\
\hline & $225 \mu 1 / \mathrm{L}$ & Most fishes found upside down within 2 minutes \\
\hline & $250 \mu 1 / \mathrm{L}$ & All fishes found upside down within 2 minutes \\
\hline \multirow[t]{3}{*}{ Benzocaine } & $30 \mathrm{mg} / \mathrm{L}$ & $\begin{array}{l}\text { Some fishes found immobilized and some with little } \\
\text { mobility within } 2 \text { minutes }\end{array}$ \\
\hline & $40 \mathrm{mg} / \mathrm{L}$ & All fishes found completely immobilized within 2 minutes \\
\hline & $50 \mathrm{mg} / \mathrm{L}$ & All fishes found upside down within 2 minutes \\
\hline \multirow{5}{*}{$\begin{array}{l}\text { Tertiary amyl } \\
\text { alcohol } \\
\text { (2-methyl 2- } \\
\text { butanol) }\end{array}$} & $1.5 \mathrm{ml} / \mathrm{L}$ & All fishes found completely immobilized within 2.5 minutes \\
\hline & $2.0 \mathrm{ml} / \mathrm{L}$ & $\begin{array}{l}\text { Half of the total fishes found upside down within } 2.5 \\
\text { minutes }\end{array}$ \\
\hline & $2.5 \mathrm{ml} / \mathrm{L}$ & $\begin{array}{l}\text { More than half of the total fishes found upside down within } \\
2.5 \text { minutes }\end{array}$ \\
\hline & $3.0 \mathrm{ml} / \mathrm{L}$ & Most fishes found upside down within 2.5 minutes \\
\hline & $4.0 \mathrm{ml} / \mathrm{L}$ & All fishes found upside down within 2.5 minutes \\
\hline Control & 0 & All fishes found were highly mobile \\
\hline
\end{tabular}

Considering the cost for transportation of rohu fingerlings at a loading density of 400 $\mathrm{g} / \mathrm{L}$, TAA was found to be most expensive followed by $2 \mathrm{PE}$ and quinaldine, however, benzocaine was found to be the cheapest (Table 2). Since TAA was unavailable and most expensive, and benzocaine does not remain effective after $3 \mathrm{~h}$ of transport (Hasan and Bart 2007a), these were not used in the transport simulation. 
Table 2. Optimum dose, time of induction and recovery period and cost of sedatives in rohu fingerling (Bangladeshi Taka = BDT; 1 US\$ = 82 BDT).

\begin{tabular}{lcccc}
\hline Sedatives & Dose & $\begin{array}{c}\text { Time required to } \\
\text { be immobilized } \\
\text { (min) }\end{array}$ & $\begin{array}{c}\text { Recovery period } \\
\text { (min) }\end{array}$ & $\begin{array}{c}\text { Cost } \\
\text { BDT/kg }\end{array}$ \\
\hline 2 Phenoxyethanol & $250 \mu 1 / \mathrm{L}$ & 4.0 to 5.0 & 5.0 to 6.0 & 9.75 \\
Quinaldine $(4 \%)$ & $175 \mu 1 / \mathrm{L}$ & 1.5 to 2.0 & 2.0 to 3.0 & 5.25 \\
Benzocaine & $40 \mathrm{mg} / \mathrm{L}$ & 2.0 to 2.5 & 2.0 to 3.0 & 2.60 \\
TAA & $1.5 \mathrm{ml} / \mathrm{L}$ & 1.5 to 2.5 & 1.5 to 2.0 & 97.50 \\
\hline
\end{tabular}

Effects of Transport Methods on the Immediate and Delayed Mortality Rate, Dissolved Oxygen Concentrations and Temperature: In the control group, 6 and $9 \mathrm{~h}$ samples had nearly 1 and $3 \%$ mortality, respectively, while $3 \mathrm{~h}$ had very low level of mortality $(<1$ $\%$ ). In quinaldine treatment group, only $9 \mathrm{~h}$ sample resulted in very little immediate mortality $(<1 \%)$, while other three sampling durations did not have any mortality. No immediate mortality was observed up to $6 \mathrm{~h}$ sampling duration and very low level $(<1 \%)$ was found at $9 \mathrm{~h}$ in the treatment group of $2 \mathrm{PE}$ (Table 3).

Table 3. Immediate and delayed mortality rates (\%) of rohu Labeo rohita fingerlings sampled from three transport simulation methods.

\begin{tabular}{cccc}
\hline Duration (h) & \multicolumn{3}{c}{$\begin{array}{l}\text { Immediate mortality rate }(\%) \\
\text { transport methods at } 1,3,6 \text { and } 9 \mathrm{~h} \text { of transport }\end{array}$} \\
\cline { 2 - 4 } & $\begin{array}{c}\text { Control }\left(\mathrm{O}_{2} \text { only) }\right. \\
2 \text { phenoxyethanol }\end{array}$ & Quinaldine \\
1 & $0.00 \pm 0.00$ & $0.00 \pm 0.00$ & $0.00 \pm 0.00$ \\
3 & $0.13 \pm 0.03$ & $0.00 \pm 0.00$ & $0.00 \pm 0.00$ \\
6 & $1.14 \pm 0.25$ & $0.00 \pm 0.00$ & $0.00 \pm 0.00$ \\
9 & $2.62 \pm 0.03^{\mathrm{a}}$ & $0.15 \pm .002^{\mathrm{b}}$ & $0.08 \pm 0.01$ \\
\hline Delayed mortality & & & \\
\hline 1 & $0.00 \pm 0.00$ & $0.00 \pm 0.00$ & $0.00 \pm 0.00$ \\
6 & $0.00 \pm 0.00$ & $0.00 \pm 0.00$ & $0.00 \pm 0.00$ \\
9 & $0.00 \pm 0.00$ & $0.00 \pm 0.00$ & $0.00 \pm 0.00$ \\
\hline
\end{tabular}

Control received only pure oxygen. Within row means $( \pm \mathrm{SE})$ with different letters are significantly different $(\mathrm{p}<0.05)$.

Mortality rates were used as the main indicators in this study which plays a central role in the management of fish seed distribution. In the control group in which no sedative was used, the observed no or little immediate mortality $(<1 \%)$ up to $3 \mathrm{~h}$ duration indicates less stressful phase and good environmental condition. Nearly 2 and $3 \%$ deaths occurred in the control group that might be associated with dropped DO level at 6 and $9 \mathrm{~h}$ transport duration. While in the quinaldine and $2 \mathrm{PE}$ treatment groups, the mortality levels observed were zero throughout the first three transport durations $(1,3$ and $6 \mathrm{~h})$ with a little immediate and delayed mortality at $9 \mathrm{~h}$ duration treatment. Such survivals could be explained by the effective sedation by $2 \mathrm{PE}$ and quinaldine which induced rapid immobilization of the fingerlings which in turn resulted in reduction in metabolism, excretion, physical stress and thus prevented deterioration of water quality. As no sedative was used in the control group the water quality particularly the DO level 
dropped below $1 \mathrm{mg} / \mathrm{L}$ which could be the underline cause of the observed little mortality. Hasan and Bart (2007a) reported (0-2 \%) mortality of rohu and silver carp fingerlings using quinaldine and benzocaine. Almost similar survival rate $(97 \%)$ was reported by Durve (1975) in mullet fry/fingerlings transport using quinaldine.

Similar to immediate mortality, levels of delayed mortality found in all three transport methods were little and similar (Table 3 ). No delayed mortality was observed in the first three treatment durations while very little $(<1 \%)$ was detected after $9 \mathrm{~h}$ of transport in all three transport methods. Levels of delayed mortality in all four transport durations were similar to that of immediate mortality.

The observed low level of delayed mortality could be associated with physical injury of fish, loss of scale, improper handling during weighing and releasing of fingerlings into the drums for the treatment. High survival in all treatments could have been a consequence of continuous use of pure oxygen. Hasan and Bart (2007a) found no delayed mortality by using low dose quinaldine and benzocaine when transported for $6 \mathrm{~h}$ at a loading density of $400 \mathrm{~g} / \mathrm{L}$ in rohu and silver carp fingerlings aided with mechanical aeration.

Successive fall in dissolved oxygen concentration was observed during four sampling durations in all three transport methods. In the control group while comparing, a significant fall in DO concentration was observed after 6 and $9 \mathrm{~h}$ during experiment but 1 and $3 \mathrm{~h}$ had, respectively, nearly 14 and $7 \mathrm{mg} / \mathrm{L}$ (Table 4). While $1 \mathrm{~h}$ sample resulted in nearly $18 \mathrm{mg} / \mathrm{L}, 9 \mathrm{~h}$ sample had only about $4 \mathrm{mg} / \mathrm{L}$ of dissolved oxygen in the quinaldine treatment group. Although a continuous fall in the DO concentration across all four transport durations was detected in the $2 \mathrm{PE}$ treatment group, it did not went below 13 $\mathrm{mg} / \mathrm{L}$.

Table 4. Dissolved oxygen concentration $(\mathrm{mg} / \mathrm{L})$ and temperature $\left({ }^{\circ} \mathrm{C}\right)$ sampled from three transport methods at 1, 3, 6 and $9 \mathrm{~h}$.

\begin{tabular}{|c|c|c|c|}
\hline \multirow[t]{2}{*}{ Duration (h) } & \multicolumn{3}{|c|}{$\begin{array}{l}\text { Dissolved oxygen concentration }(\mathrm{mg} / \mathrm{L}) \text { sampled from three transport methods } \\
\text { at } 1,3,6 \text { and } 9 \mathrm{~h}\end{array}$} \\
\hline & Control $\left(\mathrm{O}_{2}\right.$ only $)$ & 2 phenoxyethanol & Quinaldine \\
\hline Pre-loading & $28.87 \pm 0.00^{\mathrm{a}}$ & $28.87 \pm 0.00^{\mathrm{a}}$ & $28.87 \pm 0.00^{\mathrm{a}}$ \\
\hline 1 & $13.96 \pm 1.46^{\mathrm{b}}$ & $25.35 \pm 0.14^{\mathrm{a}}$ & $17.01 \pm 1.01^{\mathrm{b}}$ \\
\hline 3 & $6.49 \pm 0.62^{\mathrm{c}}$ & $18.89 \pm 1.24^{\mathrm{b}}$ & $11.52 \pm 0.43^{\mathrm{c}}$ \\
\hline 6 & $0.98 \pm 0.06^{\mathrm{d}}$ & $17.61 \pm 1.24^{\mathrm{b}}$ & $5.85 \pm 0.15^{\mathrm{d}}$ \\
\hline 9 & $0.93 \pm 0.03^{\mathrm{d}}$ & $13.36 \pm 0.95^{\mathrm{c}}$ & $3.36 \pm 0.52^{\mathrm{d}}$ \\
\hline \multicolumn{4}{|l|}{ Temperature } \\
\hline Pre-loading & $27.30 \pm 0.00$ & $27.30 \pm 0.00$ & $27.30 \pm 0.00$ \\
\hline 1 & $27.60 \pm 0.06$ & $27.53 \pm 0.03$ & $27.73 \pm 0.03$ \\
\hline 3 & $28.25 \pm 0.28$ & $28.12 \pm 0.04$ & $28.57 \pm 0.18$ \\
\hline 6 & $29.14 \pm 0.28$ & $28.77 \pm 0.03$ & $29.23 \pm 0.09$ \\
\hline 9 & $29.44 \pm 0.39$ & $28.87 \pm 0.03$ & $29.57 \pm 0.07$ \\
\hline
\end{tabular}

Within column means $( \pm \mathrm{SE})$ with different letters are significantly different $(\mathrm{p}<0.05)$.

In this study, DO concentrations dropped progressively with a negligible increase in temperature throughout the experimental durations in all three treatments. Maintaining 
high concentration of DO in 2 PE treatment group throughout the entire 9 hours study period indicates it's suitability in persisting sedation over long period. Sedation reduces oxygen consumption by reducing hyperactivity. DO concentration, however, in the quinaldine and control groups had declining trend which could be due to high consumption of oxygen resulted from increased hyperactivity of the fingerlings over duration. Reduction of the effectiveness of the sedatives with increased duration may be responsible for enhancing mobility and high consumption of oxygen by the fingerlings. While comparing, similar levels of water temperature were observed in all three treatment groups (Table 4).

We found that rohu fingerlings at $400 \mathrm{~g} / \mathrm{L}$ can be safely transported for 9 hours with no or little immediate and delayed mortality by using oxygen with or without sedatives. Use of $2 \mathrm{PE}$ and quinaldine maintains high DO concentration. .

\section{Acknowledgement}

The authors wish to thank the Ministry of Education, Govt. of the People's Republic of Bangladesh for their financial support in conducting this study.

\section{References}

Adams, S.M. 1990. Status and use of biological indicators for evaluating the effects of stress on fish. American Fisheries Society Symposium 8: 1-9. In: Adams, S.M.(ed.). Biological indicators of stress in fish. Bethesda, Maryland. $191 \mathrm{pp}$.

Barton, B.A. 2000. Salmonid fishes differ in their cortisol and glucose responses to handling and transport stress. North Am. J. Aquaculture. 62(1): 12-18.

Bell, G.R. 1964. A guide to properties, characteristics and uses of some general anesthetics for fish. Bul. Fish. Res. Board Can. 148: 11 p.

Berka, R. 1986. The transport of live fishes A review. EIFAC technical paper 48, $51 \mathrm{pp}$.

Carmichael, G.J., J.R. Tomasso, B.A. Simco and K.B. Davis. 1984. Characterization and alleviation of stress associated with hauling largemouth bass. Trans. Am. Fish. Soc. 113: 778-785.

Cooke, S.J., C.D. Suski, K.G. Ostrand, B.L. Tufts and D.H. Wahl. 2004. Behavioral and physiological assessment of low concentrations of clove oil anesthetic for handling and transporting largemouth bass (Micropterus salmoides). Aquaculture. 239: 509-529.

Coyle, S.D., R.M. Durborow and J.H. Tidwell. 2004. Anesthetics in aquaculture. Southern Regional Aquaculture Center. Publication No. 3900. 6 pp.

DoF (Department of Fisheries). 2008. Fisheries Statistical Yearbook of Bangladesh, Ministry of Fisheries and Livestock, Dhaka, Bangladesh. 42 pp.

Durve, V.S. 1975. Anesthetics in the transport of mullet seed. Aquaculture. 5: 53-63.

Ferron, A. and W.C. Leggett. 1994. An appraisal of condition measures for marine fish larvae. Adv. Mar. Biol. 30: 217-303.

Guo, F.C., L.H. Teo and T.W. Chen. 1995. Effects of anesthetics on the water parameters in a simulated transport experiment of platy fish, Xiphophorus maculatus (Gunther). Aquacult. Res. 26: 265-271.

Hasan, M. and A.N. Bart. 2006. Carp seed traders in Bangladesh: sources of livelihoods and vulnerability resulting from fish seed mortality. Asia-Pacific J. Rural Dev. 16: 101-124. 
Hasan, M. and A.N. Bart. 2007a, Improved survival of rohu, Labeo rohita (Hamilton-Buchanan) and silver carp, Hypophthalmichthys molitrix (Valenciennes) fingerlings using low-dose quinaldine and benzocaine during transport. Aquacult. Res. 38(1): 50-58.

Hasan, M. and A.N. Bart. 2007b, Effects of capture, loading density and transport stress on the mortality, physiological responses, bacterial density and growth of rohu, Labeo rohita fingerlings. Fish Physiol. Biochem. 33(3): 241-248.

Hseu, J-R, S.L Yeh, Y.T Chu and Y.Y Ting. 1998. Comparison of efficacy of five anesthetics in goldlined Sea Bream, Sparus sarba. Acta Zool. Taiwanica 9 (1): 35-40.

Hunn, J.B. and J.L. Allen. 1974. Urinary excretion of quinaldine by channel catfish. The Prog. Fish-Cult. 36(3): 157-159.

Johnson, D.L. and M.T. Metcalf. 1982. Causes and controls of fresh water drum mortality during transportation. Trans. Am. Fish. Soc. 111: 58-62.

Kumlu, M. and M. Yanar. 1999: Effects of the anesthetic quinaldine sulphate andB muscle relaxant diazepam on sea bream juveniles (Sparus aurata). Israeli J. Aquaculture. 51: 43-147.

Lambert, T.C. 1982. Techniques for the capture and handling of Atlantic mackerel with special reference to the use of quinaldine. The Prog. Fish-Cult. 44 (3): 145-147.

Lewis, D.J., G.D. Wood and R. Gregory. 1996. Trading the silver seed. University Press Limited. Dhaka-1000, Bangladesh. 199 pp.

Mazik, P.M., B.A. Simco and N.C. Parker. 1991. Influence of water hardness and salts on survival and physiological characteristics of stripped bass during transport. Trans. Am. Fish. Soc. 120: $121-126$.

McCormick, S.D., J.M. Shrimpton, J.B. Carey, M.F. O’Dea, K.E. Sloan, S. Moiyama and B.Th. Bjornsson. 1998. Repeated acute stress reduces growth rate of Atlantic salmon parr and alters plasma levels of growth hormone, insulin-like growth factor 1 and cortisol. Aquaculture. 168: 221-235.

McFarland, W.N. 1959. A study of the effects of anesthetics on the behavior and physiology of fishes. Publications of the Institute of Marine Science. 6: 23-55.

Munday, P.L.and S.K. Wilson. 1997 Comparative efficacy of clove oil and other chemicals in anesthetization of Pomacentrus amboinensis, a coral reef fish. J. Fish Biol. 51(5): 931938.

Pickering, A.D. 1992. Rainbow trout husbandry: management of the stress response. Aquaculture, 100: $125-139$.

Pickering, A.D. 1993. Growth and stress in fish. Aquaculture. 111: 51-63.

Pirhonen, J. and C.B. Schreck. 2003. Effects of anesthesia with MS 222, clove oil and $\mathrm{CO}_{2}$ on feed intake and plasma cortisol in steelhead trout (Oncorhynchus mykiss). Aquaculture. 220: 507-514.

Sado, K.E. 1985. Influence of the anesthetic quinaldine on some tilapias. Aquaculture. 56: 55-62.

Sills, J.B. and J.L. Allen. 1973. The influence of $\mathrm{pH}$ on the efficacy and residues of quinaldine. Trans. Am. Fish. Soc. 100: 544-545.

Smit, G.L. 1980. The effect of tricaine methane sulphonate and generally used anticoagulants on fish haematology. Ph.D. Thesis, University of the Witwatersrand, Johannesburg.

Weil, L.S., T.P. Barry and J. A. Malison. 2001: Fast growth in rainbow trout is correlated with a rapid decrease in post-stress cortisol concentrations. Aquaculture. 193: 373-380. 